\title{
240 ЛЕТ НА РОССИЙСКОЙ ЗЕМЛЕ (ИЗ ИСТОРИИ ОСНОВАННОГО АРМЯНАМИ ГОРОДА НОВОГО НАХИЧЕВАНА)*
}

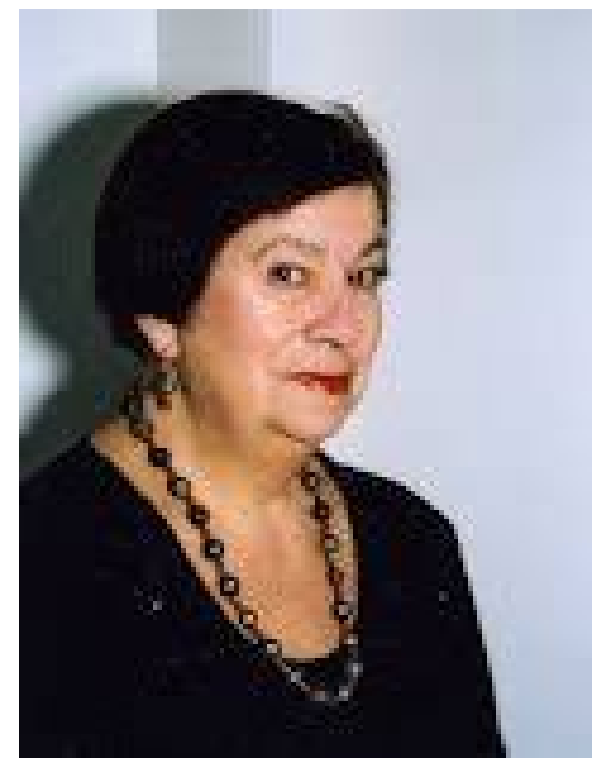

Статья посвящена истории города Нового Нахичевана, основанного в 1779 г. переселенными по указу Екатерины II из Крыма в Россию армянами, получившими при этом от правительства ряд льгот и привилегий. Новый город успешно развивался и благоустраивался за счет купеческой торговли, развития ремесел, промышленности, благотворной деятельности меценатов, способствовавших строительству в нем учебных заведений, иерквей, театра, музея и других культурных объектов, в результате чего он вскоре стал одним из экономически и культурно важных иентров на Юге России. Но с присоединением Нового Нахичевана в декабре 1928 г. к соседнему городу Ростову-на-Дону, в котором он первое время существовал в виде Нахичеванского района, а затем с переименованием в 1929 г. в ни о чем не говорящий Пролетарский район, историческое название города, в котором прочно сохранялся национальный быт его жителей и уроженцами которого были многие вылдющиеся армяне, исчезло, а в дальнейшем, особенно в 19201930-е г2. сталинских репрессий, существенно пострадали и сам город, и его известные горожане. В наше время, на фоне возрождающегося интереса к своей истории, донскими армянами все чаше стали высказываться пожелания о возвращении городу его прежнего названия, что стало бы актом большого нравственного значения.

Ключевые слова: армянские переселенцы из Крыма, новый город и его развитие, купеческая торговля, ремесла, промышленность, культурные объекты

Тер-Саркисянц Алла Ервандовна (1937-2019) - д.и.н., главный научный сотрудник отдела Кавказа Института этнологии и антропологии РАН (РФ, Москва, Ленинский пр. 32А). Эл. почта: aeters@yandex.ru. Ter-Sarkisyants Alla E. - Institute of Ethnology and Anthropology, RAS (Russia, Moscow. Leninsky pr.32A). E-mail: aeters@yandex.ru

* Публикуется в соответствии с планом научно-исследовательских работ Института этнологии и антропологии РАН 
14 ноября 2019 г. исполнилось 240 лет, как переселенными по указу императрицы Екатерины II от 9 марта 1778 г. из Крыма в Россию армянами был основан в низовьях Дона город, получивший название Новый Нахичеван. К тому времени начатая Турцией под давлением Франции и Австрии русско-турецкая война 1768-1774 гг. была закончена победой России и заключением 15 июля 1774 г. Кучук-Кайнарджийского мирного договора, согласно которому к России отходили земли от Буга и крепости Кинбурн при устье Днепра до Азова с Прикубаньем и Приазовьем, крепости Керчь и Еникале, дававшие контроль над выходами из Азовского в Черное море. Кроме того, Россия добилась признания под своим покровительством независимости бывшего прежде вассалом Турции Крымского ханства, новым (и последним) ханом которого стал ее ставленник Шагин-Гирей (1745-1787), по просьбе которого в Крыму оставались русские войска. Но в самом ханстве обстановка была сложная, поскольку в то время его раздирали противоречия между прорусской и протурецкой группировками. Поэтому, по мнению ряда исследователей, одной из целей намеченного переселения из Крыма христианского греческого и армянского населения было экономическое ослабление ханства (хотя оно по существу уже находилось под властью России), которое с уходом греков и армян лишилось бы уплачиваемых ими податей, составлявших главный источник доходов ханства, и облегчило бы тем самым окончательное включение его земель в состав Российской империи. Вскоре это произошло, когда в 1781 г. Екатерина II посоветовала уставшему от постоянного кризиса Шагин-Гирею отказаться от ханства и передать Крым России, на что тот был вынужден согласиться. Этот акт был закреплен в Манифесте Екатерины II от 8 апреля 1783 г. (Черняховский, Черняховская 2015: 169-171).

По мнению ряда исследователей, одной из целей акции переселения было создание на юге страны форпоста из представителей христианских народов против возможной турецкой агрессии, однако еще более важной причиной было стремление заселить для хозяйственного освоения вновь приобретенные Россией обширные и практически безлюдные степные территории предприимчивыми и трудолюбивыми людьми, имеющими большой опыт в земледелии, торговле и ремеслах. Кроме того, было известно, что многие будущие армянские переселенцы обладали знаниями восточных языков и даже обычаев народов, с которыми они контактировали во время проживания в Крыму, что имело бы значение для развития торговых отношений России со странами Востока. Существенное значение имело и то обстоятельство, на которое в свое время обратил внимание ростовский историк Саркис Суренович Казаров, что армянские переселенцы по уровню своего развития резко отличались от тогдашнего российского общества, в котором господствующую роль играло дворянство, а в помещичьих хозяйствах и в промышленности преобладал принудительный труд крепостных. Общество крымских армян, не знавшее ни привилегированных дворян, ни бесправных крепостных, было по своей сути буржуазным (хотя и далеко неоднородным в социальном отношении), ведущая роль в нем принадлежала городской буржуазии, что давало благоприятные предпосылки для продолжения крымскими армянами их успешной предпринимательской деятельности, которую они вели в Крыму и в новых условиях на донской земле (Казаров 2012: 14, 15). Переселенцам было обещано отвести на новом месте 86 тыс. десятин земли и разрешено основать один город и пять селений.

В то же время надо отметить, что переселение армян из благодатного Крыма вряд ли было добровольным, поскольку многие из них, особенно небогатые сель- 
ские жители, не хотели оставлять свои насиженные места с ухоженными садами, виноградниками и огородами, приносящими им доход, а также покидать могилы своих предков. Не сопротивлялись переселению в основном зажиточные купцы, которые полагали в дальнейшем на обширной российской территории расширить свою торговую деятельность. В свое время об этом писал армянский историк Лео (1860-1932), по его словам, «армянский народ, более 400 лет обживавший великолепные местности Крыма, не желал покидать свои обустроенные дома и отправляться на чужие земли. Не согласны были и татары, которые не раз обращались к Шагин-Гирею как от своего имени, так и от имени переселенцев противостоять русским замыслам» (цит. по: Геворкян 2012: 342).

Действительно, жившие в основном в горах крымские татары, от которых ни армяне, ни греки, проживавшие преимущественно на побережье, не терпели каких-либо серьезных притеснений, не хотели отпускать армян, мотивируя это тем, что среди них много ремесленников и если они покинут Крым, то это отрицательно скажется на его хозяйственной ситуации; лишь вмешательство турок всегда представляло для армян реальную угрозу. Упрекая армян в нежелании покидать полуостров, командующий русскими войсками в Крыму, уже достаточно популярный тогда генерал-поручик Александр Васильевич Суворов, который должен был по заданию правительства осуществлять их переселение, даже угрожал армянам новой войной с Турцией, в ходе которой, по его словам, русская армия не будет их защищать (Казаров 2015: 30). О негативной роли предстоящей турецкой угрозы для крымских армян говорил и глава армянской епархии в России архиепископ Иосиф Аргутинский (1743-1801), который обратился к ним с призывом покинуть Крым и переселиться в Россию, где они и их потомки могли бы спокойно жить.

Лишь после убедительного обращения архиепископа крымские армяне были вынуждены согласиться на переселение, которое началось летом 1778 г. под руководством А.В. Суворова, их духовного главы архимандрита Петроса Маркосяна и капитана русской армии Степана Чалхушьяна. Сыграло роль и то обстоятельство, что командованию для ускорения начала переселения пришлось подкупить главных действующих лиц этой акции. Так, Шагин-Гирей, получив 50000 руб. и драгоценные подарки, перестал препятствовать переселению, митрополиту греков Игнатию выделили 6500 руб., архимандриту крымских армян Петросу Маркосяну - 2820 руб., деньги получили и другие лица.

Караван переселенцев был разделен на несколько групп в зависимости от места проживания их в Крыму, при этом каждую из них возглавлял свой священник. Первыми в путь двинулась самые многочисленные жители города Кафы во главе со священником Тер-Мартиросом, за ними направились жители других городов и сел. Предварительно Петрос Маркосян подготовил список вывозимых из Крыма разного рода ценностей, в том числе священных реликвий, с подробным указанием того, кому и что передать в будущем при возведении на новом месте церквей.

Мучительный полуторагодичный переход на север по бездорожью и рано наступившими заморозками, а затем встречей с суровой зимой, которую переселенцы были вынуждены провести в землянках, под открытым небом, был сначала направлен к месту предполагаемого заселения, расположенного недалеко от Екатеринослава, на реке Самаре, притоке Днепра. Однако на новом месте не оказалось свободных земель для строительства переселенцами собственных поселений, а размещаться 
среди местных жителей они категорически не захотели. В результате предоставленные там условия, да и сама местность не удовлетворили крымских армян, в связи с этим они обратились к властям с просьбой пересмотреть вопрос о месте их будущего жительства, тем более, что для греческих переселенцев были выбраны более удачные места в районе Мариуполя и Таганрога.

Глубочайшую утрату переселенцы пережили в связи с кончиной в январе 1779 г. на берегах Самары ставшего их духовным руководителем Петроса Маркосяна, до этого около 60 лет служившего в Св. Эчмиадзине. Смерть настигла его в тот момент, когда он, несмотря на свой чересчур преклонный возраст, собирался отправиться в Санкт-Петербург для окончательного решения вопроса о месте заселения армян. Предложенное властями новое место в низовьях Дона, восточнее основанной в середине XVIII в. крепости Св. Димитрия Ростовского, оказалось более предпочтительным в природно-географическом отношении благодаря нахождению его на перекрестке сухопутных и водных артерий, близостью к нему торговых путей, наличию судоходной и богатой рыбой реки Дон, похожими на крымские, хотя и несколько более суровыми климатическими условиями. С наступлением весны 1779 г. караван переселенцев отправился на юго-восток, к новому месту расселения.

Долгая и утомительная дорога приносила переселенцам неисчислимые страдания от холода, недоедания, болезней. Несмотря на то, что им по дороге, в результате заботы А.В. Суворова, неоднократно обращавшегося к князю, генерал-фельдмаршалу Григорию Александровичу Потемкину по поводу бедственного положения, оказывалась определенная помощь продуктами, одеждой, транспортом, деньгами, этого было явно недостаточно. По словам известного в то время просветителя и историка

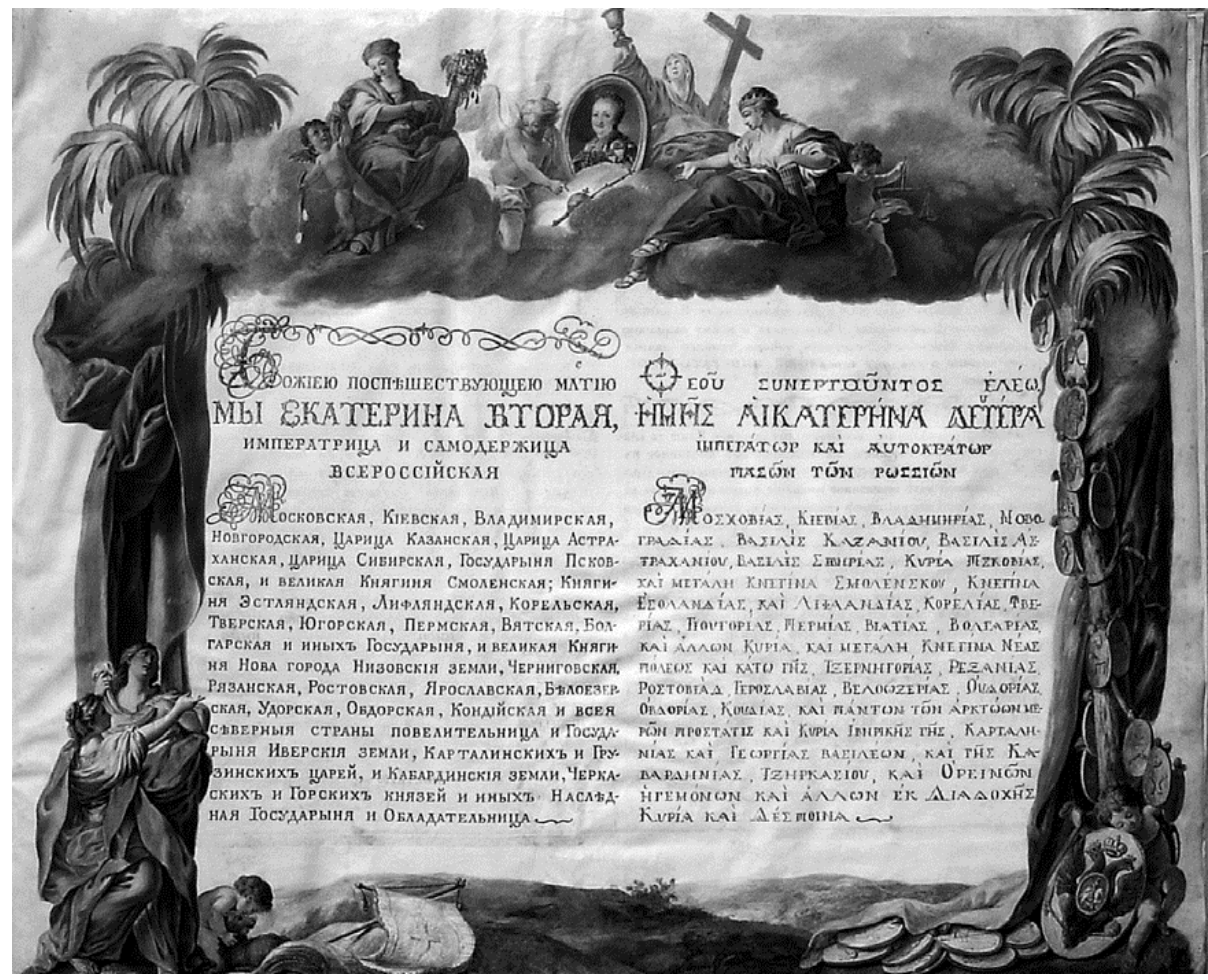

Первый лист Жалованной грамоты (Указа) Екатерины II от 14 ноября 1779 г.) 
Ерванда Овакимовича Шахазиза (1856-1951), «не выдержав сурового непривычного климата, трудностей длительного путешествия, лишенные теплой одежды, питательной пищи, люди умирали сотнями и невзрачными своими могильными холмиками украшали эту однообразную, скучную и пыльную степь» (цит. по: 210 лет в семье единой 1989: 3).

В результате столь тяжелого перехода, унесшего множество человеческих жизней, к ноябрю 1779 г. армянские переселенцы, которых в живых осталось из общего числа вышедших из Крыма 12598 человек только 9050, дошли до низовий Дона. К этому времени к ним подоспел привезенный полковником Иваном Абрамовым (Ованесом Абрамяном) из Санкт-Петербурга составленный из пяти пунктов на русском и армянском языках и подписанный 14 ноября 1779 г. Екатериной II указ (Жалованная грамота), согласно которому переселенцы получали от имени императрицы различные льготы и привилегии: освобождение от государственных податей и служб на 10 лет, от воинской повинности - на 100 лет, им разрешались строительство церквей и проведение в них обрядов в соответствии с собственными законами и традициями, свободная торговля внутри и вне государства; они получали право строить своими силами фабрики, заводы, купеческие мореходные суда. Дата этого указа считается и официальной датой основания нового города Нахичевана.

Из 12,6 тыс. армянских переселенцев, вышедших из Крыма, подавляющее большинство - более 11 тыс. - были жителями крымских городов Кафы (5511 человек), Карасубазара (2809), Бахчисарая (1375), Гезлева (1304), Акмечети (259) и Старого Крыма (160). Число сельских переселенцев составило 1,2 тыс. человек. С собой переселенцы, среди которых было немало предпринимателей в разных сферах деятельности, вывезли, помимо денежных средств, оборудование принадлежавших им заводов; те из них, кто занимался виноградарством или скотоводством, взяли с собой саженцы крымских сортов винограда, пригнали из Крыма большие отары породистых овец, которые давали много качественного сала.

Прибыв на донскую землю, армянские переселенцы ранней весной 1780 г. приступили к строительству, практически на пустом месте, нового города, для чего в первую очередь стали запасаться строительными материалами. Поэтому сначала из Царицына ими было доставлено большое количество леса и сибирского железа. Бывшие владельцы в Крыму разных заводов - кирпичных, черепичных, кожевенных, салотопных, спиртоводочных и свечных - в течение лета того же года сумели восстановить свои предприятия на новом месте. Обнаруженные на правом берегу реки Темерник богатые запасы известняка позволили новопоселенцам открыть каменоломни с целью добычи так называемого аршинного камня. Тучные донские пастбища способствовали развитию овцеводства, что привело сразу же к организации производства на салотопных заводах, на базе которых затем были открыты мыловаренные, свечные, кожевенные предприятия; одновременно на берегу Дона были организованы шерстомойки (Казаров 2012: 15-16).

Среди многочисленных предметов своей оставленной в Крыму богатой духовной культуры переселенцы привезли на Дон более 300 украшенных миниатюрами манускриптов, самый старый из которых датировался 1212 годом, около 800 средневековых хачкаров (крест-камней), в том числе и вывезенный в свое время их предками в Крым из армянской столицы периода Багратуни г. Ани хачкар XI в. Сурб Хач (Святой Крест), по названию которого в окрестностях Старого Крыма ими был построен в 
1358 г. монастырь Сурб Хач, где этот хачкар находился в течение нескольких веков. Среди вывезенных ценностей были личная библиотека Петроса Маркосяна, множество церковной утвари, в том числе золотые и серебряные сосуды и кресты, богатые одеяния священников, ковры и целый ряд других предметов национального искусства.

21 апреля 1781 г. в торжественной обстановке, в присутствии архиепископа Иосифа Аргутинского, который после смерти архимандрита Петроса Маркосяна взял на себя заботы по сохранению и распределению всех ценностей, вывезенных из Крыма, и стал духовным главой переселенцев, была проведена закладка будущего города, который он благословил и дал ему название Нор Нахичеван (Новый Нахичеван), что означало «Новое пристанище», которое армяне обретали в России. В этот день архиепископ провел торжественную литургию и окрестил все четыре священных камня, которые нужно было заложить с четырех сторон строящегося города. Затем во главе с ним все нахичеванское духовенство в составе 120 архиереев и архимандритов торжественным ходом поочередно заложили эти камня в нужные места. Торжество закончилось праздничным салютом, который оповестил об основании города. Тогда же был принят первый генеральный план застройки Нового Нахичевана. По этому плану город был разбит на ровные кварталы, пересекающиеся в нем под прямым углом улицы и переулки-линии напоминали планировку застройки Васильевского острова в Санкт-Петербурге, где преимущественно жили местные армяне.

Главной площадью Нового Нахичевана стала Соборная по названию заложенного на ней 9 сентября 1783 г. главного Кафедрального собора в честь Св. Григория Просветителя (Сурб Григор Лусаворич). План этого храма, по поручению Екатерины II, был составлен крупным архитектором того времени Иваном Егоровичем Старовым с использованием проекта итальянских мастеров, который возводил тогда Таврический дво-

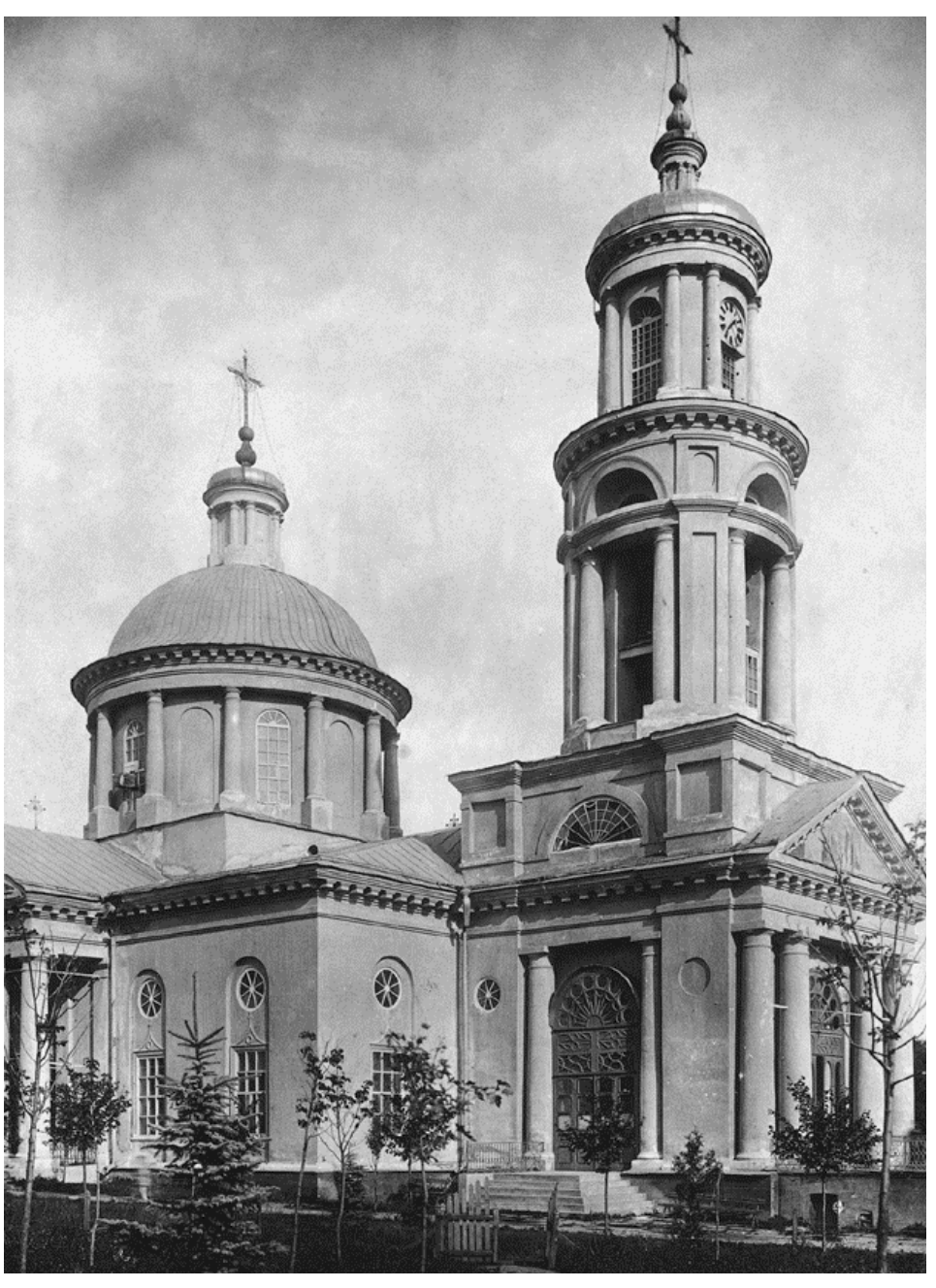

Храм во имя Св. Григория Просветителя. 1814 г. 
рец в Санкт-Петербурге. Дошедшее до нас предание гласит, что императрица сказала ему: «Ты строишь Таврический дворец, а теперь для таврических переселенцев строй хороший собор» (цит. по: Вартанян, Казаров 2008: 9).

Строительство величественного собора, предпринятое в основном переселенцами из Кафы, было завершено в 1814 г. Однако при советской власти свершилось моральное преступление по отношению к донским армянам, которые за годы проживания на донской земле превратили этот степной край в экономически и культурно развитый. Сначала в ночное время 18 июля 1959 г. собор закрыли, с него сняли крест и колокола, а затем в 1966 г. он был взорван и полностью разрушен. Никакого ответа на свое коллективное письмо по поводу спасения их храма на имя председателя Президиума Верховного Совета СССР Л.И. Брежнева от 9 августа 1960 г. нахичеванцы не получили.

Одновременно в Новом Нахичеване были основаны и другие церкви. Самой первой из них была построенная в византийском стиле церковь во имя Успения Пресвятой Богородицы (Сурб Аствацаџин), освященная в день Пасхи 4 апреля 1781 г. архиепископом Иосифом Аргутинским. В том же 1781 г. были заложены еще две церкви - во имя Св. Николая (Сурб Никогайос), также построенная в византийском стиле и освященная 10 сентября 1783 г., и основанная Иосифом Аргутинским церковь во имя Св. Вознесения (Сурб Амбариум), церемония освящения которой проходила в присутствии множества людей и закончилась приглашением со стороны полковника Ованеса Абрамяна ее участников на праздничный обед в его доме. Две церкви были основаны в 1783 г. - заложенная в праздник Св. Тороса церковь во имя Св. Теодороса (Сурб Торос), построенная также в византийском стиле и освященная 22 ноября 1786 г., и церковь в честь Св. Георгия Победоносца (Сурб Геворг), освященная 5 декабря 1787 г. (Вартанян, Казаров 2008: 9-11).

Эти пять церквей в 1960-е годы постигла та же трагическая судьба, что и Кафедральный собор. Уцелела лишь одна, самая поздняя церковь, построенная на городском кладбище. Эта церковь Св. Иоанна Предтечи (Сурб Kapanem) была основана по завещанию местной дворянки и благотворительницы Акюлине Погосовны Аладжаловой в 1875 г. и освящена 11 июня 1881 г.

Чтобы переселенцам было легче обживаться на новом месте и не слишком тосковать по своей прежней родине в Крыму, и после присоединения его к России в 1783 г. не иметь желания возвращаться туда, Иосиф Аргутинский стал прилагать немало усилий. Так, в 7 км от тогдашней границы Нового Нахичевана он заложил в 1783 г. монастырь и назвал его Сурб Хач (Святой Крест), т.е. дал ему название монастыря 1358 г., оставленного армянами в Старом Крыму; затем он в 1789 г. выкупил в Санкт-Петербурге армянскую типографию Григория Ходжамаловича Халдаряна (после его кончины в 1788 г.), перевез ее в Новый Нахичеван и установил в 1790 г. при монастыре Сурб Хач. Это была первая на Юге России армянская типография, в которой в 1790-1796 гг. (в 1796 г. эта типография была переведена в Астрахань) печатали периодику и книги на армянском и русском языках. Тогда же при монастыре была основана школа-пансионат для детей неимущих армян. Таким образом, монастырь Сурб Хач вскоре со времени переселения армян стал их духовным центром. Его церковь, построенная в стиле русского классицизма по проекту того же архитектора И.Е. Старова в 1792 г., стены которой были украшены привезенными армянами на Дон хачкарами (уничтоженными в 1960 г.), является единственным сохранившимся памятником XVIII в. вблизи основанного армянами города. 
Согласно указу Екатерины II, созданная на Дону армянская колония получила возможность решать свои внутренние проблемы самостоятельно: всем управлял имевший полные права городского самоуправления, существовавшие тогда в Российской империи, магистрат, состоявший из двух отделов - армянского и общего. Избираемый сроком на три года, армянский отдел магистрата заведовал всеми делами, за исключением уголовных дел, которые передавались в общий отдел и рассматривались в соответствии с действовавшими тогда общегосударственными законами. Армянский отдел магистрата совмещал в себе судебные, полицейские, административные и финансовые функции. Он состоял из председателя, которым был городской голова, и четырех заседателей, двое из которых ведали судебной частью, двое - полицейскими функциями. Кроме того, колония имела и свою печать. Языком делопроизводства на ее территории был армянский.

После реорганизации магистрата в 1868 г. для создания впоследствии городской управы было выстроено новое здание, а бывшее здание магистрата стало в 1872 г. собственностью таганрогских купцов Гайрапетовых. В дальнейшем, вплоть до 1917 г., его здание использовалось под гостиницу, а в годы Гражданской войны в нем разместился краевой Армянский музей древности и искусства, организованный по инициативе бывшего ректора Нахичеванской духовной семинарии Ерванда Овакимовича Шахазиза. Но этот музей просуществовал недолго. После того, как в 1921 г. в Ереване был основан Культурно-Исторический музей, в 1922 г. туда, из-за боязни утраты его экспозиции, был вывезен весь Армянский музей, а бывшее здание магистрата превращено в коммунальное жилье, портал фасада которого впоследствии был разобран и на нем не была установлена даже мемориальная доска (Багдылков 2011: 37-38).

Императором Александром I был утвержден 2 августа 1811 г. собственный герб Нового Нахичевана. Он представлял собой прямоугольный щит, разделенный по диагонали на две равные части. Слева на серебряном фоне расположены в три ряда шесть золотистых пчел, в соответствии с числом городских приходов - Соборный, Никольский, Успенский, Георгиевский, Федоровский и Вознесенский, образованных армянами, переселившимися из шести городов Крыма. Правую часть щита занимал золотистый улей на зеленом фоне, геральдически символизирующий трудолюбие армянского народа. (Багдылков 2011: 19).

С самого начала основания в Новом Нахичеване вокруг строящегося в центре города собора во имя Св. Григория Просветителя стали возникать небольшие торговые постройки, магазины и лавки торговцев хлебом и различными съестными припасами, одеждой - обувью, шапками и тулупами, разного рода ремесленные мастерские ювелиров, кузнецов, каменщиков, жестянщиков и др., ларьки сапожников, пошива одежды, часовых мастеров, продавцов кожи, плотников, парикмахеров и др. Уже к этому времени в городе насчитывалось 72 вида ремесел. В 1789 г., т.е. спустя 10 лет после прибытия армян на Дон, в их новом городе уже существовали «180 крытых черепицею лавок, 9 заводов, сафьяновых - четыре, красильных бумажных вещей -1 , шелковых турецкой фабрики - 2, купеческих и мещанских домов каморных - 337, мазанок - 23, деревянных - 1688, купцов, мещан и цеховых - 1040» (Казаров 2012: 18-20).

В 1793 г. Новый Нахичеван посетил один из крупнейших естествоиспытателей XVIII - XIX вв., член Санкт-Петербургской академии наук Петр Симон Паллас (17411811), предпринявший поездку по Югу России с научной целью. Хотя дневниковые записи П.С. Палласа, содержащие собранный им богатый материал о быте народов 
Новороссии, не были опубликованы, однако в свое время ростовский краевед Михаил Борисович Краснянский в Румянцевском музее Москвы сделал некоторые выписки из его записей и опубликовал их. О своем пребывании в Новом Нахичеване П.С. Паллас писал: «Я проехал по этой второй балке и прибыл к новому армянскому городу Нахичевану, отстоящему в 14 верстах. Это одна из колоний армянской нации, основанная во время краткого царствования Великой Екатерины, обещает много в будущем. Промышленность армян стоит гораздо выше промышленности русских и греков и даже выше промышленности первых русских колонистов; у них есть фабрики, ремесленные и торговые заведения, так что всякий человек, любящий свою страну, должен желать переселения с равнин Аракса в Россию этого народа, в настоящее время столь страдающего под игом Турции... Город Нахичеван был основан в ноябре (14-го) 1779 года наиболее богатыми ремесленниками и купцами из крымских армян после заключения Кучук-Кайнарджийского мира, когда русские войска под начальством генерала Суворова оставили эту страну. Большая часть христиан, на которых лежала вся промышленность и торговля Крымского полуострова, к концу осени выехала из Крыма, хотя многие это сделали с болью в сердце по совету греков, живших на южном склоне Крымских гор, и не ожидали ничего хорошего от возвращения татар. Я видел некоторые первоначально построенные жалкие хижины, сколоченные наскоро под страхом возвращения магометан, не исполнявших приказания русской императрицы; но большая часть жителей Нахичевана живут теперь в хорошеньких каменных домиках, крытых черепицею; кроме того они построили на собственный счет городскую думу, с красивою квадратною площадью перед ней, окруженную лавками, где можно купить продукты их производства, всякого рода съестные припасы и очень хороший хлеб, испеченный на азиатский манер в булочных. Сбыт всех этих продуктов в соседнюю округу очень велик, потому что среди казаков мало ремесленников. Тут есть 3 церкви, не считая монастыря с церковью, выстроенного из тесаного камня в 8-ми верстном расстоянии от города, по направлению к Ростовской крепости, улицы расположены правильно и параллельно р. Дону. Дома поставлены довольно далеко один от другого и снабжены всеми необходимыми удобствами; деревянные дома обмазаны глиною, покрыты черепицею и, таким образом, гарантированы от огня. Большая часть жителей состоит из купцов и ремесленников, в числе которых есть кожевники, портные, тележники, кузнецы, ткачи, столяры, горшечники, каменщики и т.п.; булочники пекут отличный ржаной и пшеничный хлеб, тогда как в России из всех наций Европы наименее произрастает искусство хлебопечения...» ( цит. по: Бархударян 1996: 522-524).

В 1812 г. генерал Илья Андреевич Безбородко (1756-1815) оставил о своем посещении Нахичевана следующую запись: «2 сентября из Аксая выехал в Нахичеван, армянский город Екатеринославской губернии, круговою дорогою - 20 верст от Аксая. Был в гостином дворе, город многолюдный, регулярно расположены улицы. Строения в армянском вкусе. Дома чистые, по большей части покрыты черепицею. Есть и хорошие каменные дома. Церквей каменных несколько, довольно огромные! Садов много. Положение города прекрасное - на горе при реке Дон». Герой Отечественной войны 1812 г. генерал Николай Николаевич Раевский (1771-1829) во время поездки на Кавказ, предпринятой в 1820 г, вместе с А.С. Пушкиным, о посещении Нахичевана писал: «За крепостью есть другой форштат или город армянский, Нахичеван называемый, пространный, многолюдный и торговлей весьма богатый. Образ жизни, строенье, лица, одеяние, - все оригинальное» (оба отрывка цит. по: Багдыков 2011: 54-55). 
Содержательные путевые заметки о своих впечатлениях оставил известный русский заводчик и меценат Анатолий Николаевич Демидов (1812 - 1870), посетивший в 1837 г. во время своего путешествия по Югу России Новый Нахичеван по приглашению его жителей: «Нахичеван - город замечательный по своей странной наружности, свидетельствующий, впрочем, о господствующей здесь торговой деятельности... Народонаселение Нахичевана отличается смышленостью и ловкостью в торговле... Хотя Нахичеван находится не в таком счастливом географическом положении, как Ростов, зато жители его несравненно способны к торговым сделкам, нежели ростовчане. Из глубины этой пустыни, почти никем не посещаемой, они содержат постоянные торговые отношения со своими соотечественниками, живущими в Астрахани, Лейпциге и Малой Азии. В доказательство их ловкости достаточно будет сказать, что они овладели почти всею торговлею Донского бассейна. По причине своих многочисленных базаров Нахичеван превратился в богатое складочное место, способное, в случае надобности, наводнить товарами все окрестные ярмарки. Искусные нахичеванские армяне не преминули скупить и все вино, доставляемое донскими виноградниками; они развозят его по всей Южной России и сбывают под именем шатолафита или госотерна. Многочисленные магазины этого небольшого города наполнены прекрасными шелковыми тканями и разными восточными, преимущественно персидскими, товарами. Улицы здесь прямые, и так же, как дома, содержатся в большой чистоте. Мы остановились в доме городского головы, который принял нас чрезвычайно радушно и приветливо. Здесь нам не понравилась только чрезвычайная дикость женщин, простирающаяся до того, что мы едва имели случай увидеть, и то вскользь, огромные косы здешних красавиц, расположенные на голове венцом, и их шелковые платья» (Патканян 1968: 264: цит. по: Казаров 2012: 17; Багдыков 2011: 56-57).

Таким образом, уже в первые десятилетия после своего основания Новый Нахичеван, по свидетельству очевидцев, представлял собой экономически развитый город благодаря не только мелкой торговле, чем были вынуждены в первое время заниматься многие горожане с целью элементарного выживания, но в основном благодаря сметливости крупных армянских предпринимателей-купцов, восстановлению и налаживанию ими прежних связей со своими торговыми партнерами в разных городах не только России, но и других стран, открытию ими крупных магазинов, а также процветанию разных видов ремесел.

В дальнейшем, чтобы отличаться от древнего армянского города Нахиджевана в Закавказье, расположенного на берегу реки Аракс и присоединенного по Туркманчайскому договору 1828 г. с Ираном в составе Восточной Армении к России, Новый Нахичеван в 1838 г. был официально переименован Сенатом в Нахичевань-на-Дону.

В постепенно благоустраивающемся городе Нахичевани-на-Дону, численность населения которого к 1850 г. составила 15 тыс. человек (для сравнения укажу, что в соседнем Ростове-на-Дону было в том же году 11 тыс. человек), быстро развивались промышленность и торговля, мостились камнем улицы, благоустраивались набережная и порт, росло число школ, в том числе и частных, было открыто уездное училище. Позднее в городе открылись женская и мужская гимназии, Армянское ремесленное училище, в котором, наряду с общеобразовательными предметами, учеников обучали различным ремеслам: токарному, столярному, сапожному и другим (1880), и училище для девочек (1881), женское Гогоевское училище (1882), еще несколько 
школ, бесплатная библиотека-читальня, Общество любителей драматического искусства, клубы, также основан механический чугунно-меднолитейный завод Григорьева (1891), открыты больницы, духовная семинария, приют для кавказских армян, Общество попечительства над бедными армянами; в Александровском саду установлена высотой 8,5 м в честь императора Александра II Александровская колонна, которую венчал позолоченный двуглавый орел (1894), выстроено здание городского театра (1899), появились электрическое освещение и водопровод, заработал телефон, были разбиты городские парки, до Ростова пущена конно-железная дорога (1890), затем электрический трамвай (1902), до монастыря Сурб Хач - автобусная линия (1904), на заводе «Аксай» произведен выпуск партии легковых автомобилей «Олдсмобиль» (1904), построены судоремонтные мастерские (1912), открыт кинотеатр «Эльдорадо» (1913), основан завод «Мыловар» (Сармакешян 1990; Ананян, Хачатурян 1993: 106-107; Багдыков 2011: 4-7).

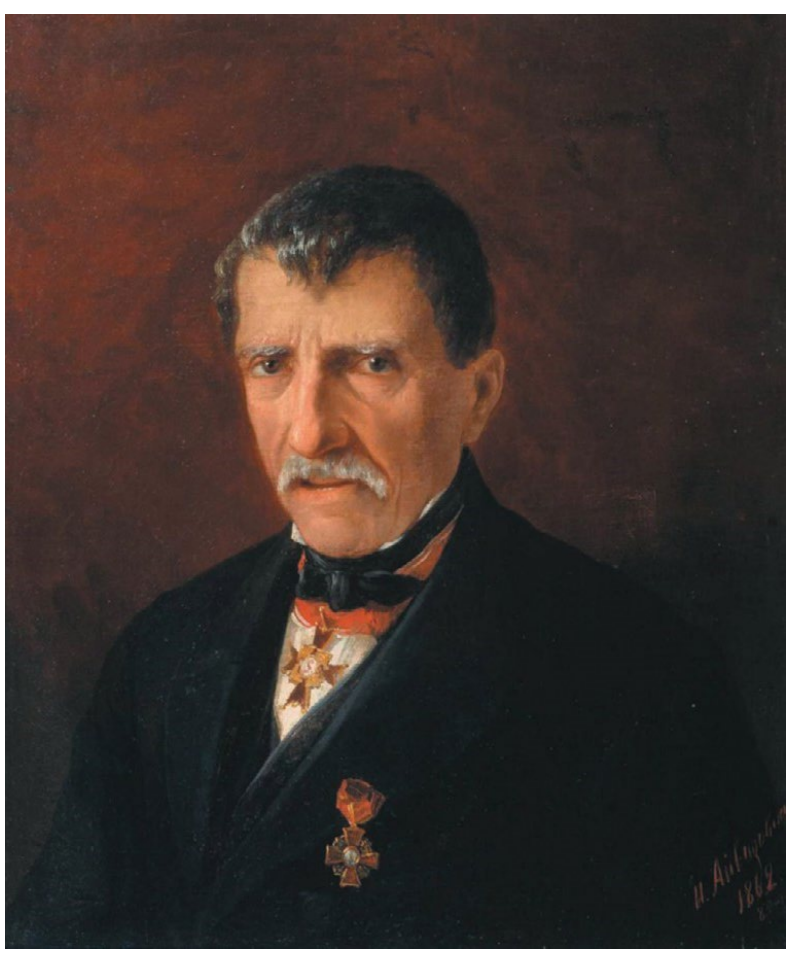

Портрет городского головы А.П. Халибова кисти И.К. Айвазовского. 1862 г.

Значительная роль в экономическом развитии города принадлежала нахичеванским купцам, их активной торговой и фабрично-заводской промышленной деятельности. Все они пользовались в городе большим авторитетом, неоднократно избирались на высокие должности, многие в течение нескольких лет становились городским головой, гласным Городской думы, членами разных обществ, почетными гражданами, кавалерами орденов и медалей. Среди них особенно выделялся своим авторитетом Артемий Павлович Халибов, избиравшийся с 1833 по 1835 и с 1842 по 1853 гг. городским головой родного для него города Нахичевани-на-Дону и являвшийся фактическим руководителем армянской общины. Занимая столь высокую должность, он умело руководил городским бюджетом, не допуская его дефицита, хорошо ладил с теми, от кого зависело благополучие как Нахичевани, так и его самого, например, с таганрогским градоначальником бароном Отто Германовичем Франком, имел доверительные отношения с архиепископом, а затем и католикосом всех армян Нерсесом Аштаракеци, что позволяло ему отстаивать интересы и независимость города, сохранять дарованные Екатериной II привилегии и не допускать присоединения его к Ростову. Одновременно А.П. Халибов осуществлял немалую благотворительную деятельность. Так, он пожертвовал 50 тыс. руб. на содержание училища для армянских юношей, основанное в 1858 г. Габриелом Айвазовским в 
Феодосии, которое было названо по его имени Халибовским; кроме того, не дожидаясь в Нахичевани открытия духовного училища, он пожертвовал в его фонд 20 тыс. руб.; во время Крымской войны на нужды Черноморского флота отправил 10 тыс. пудов каменного угля; после ухода из жизни в 1865 г. своего друга и компаньона Никиты Христофоровича Гогоева он, выполняя его духовное завещание, вплоть до своей смерти вносил деньги на содержание созданного его другом женского училища, вошедшее в историю как Гогоевское. В хороших отношениях А.П. Халибов был с братьями Айвазовскими, при этом с Иваном Константиновичем он состоял в переписке. Выполненный в 1862 г. И.К. Айвазовским портрет Артемия Павловича хранится в Ростовском областном музее изобразительных искусств.

Как отмечают исследователи, именно на активной деятельности нахичеванских купцов держалось богатство и благосостояние города. В то же время в своем быту армянские купцы вели довольно скромный образ жизни, были экономны и расчетливы (но не скупы, особенно когда дело касалось празднования на «широкую ногу» со своими компаньонами и друзьями удачных торговых сделок), не позволяя себе лишние траты. Вот как, например, писал об этом один из современников: «Вы посмотрите, чем питается купец-армянин, получавший в год чистого дохода от 5 до 15 тысяч рублей. Он ест баранину, местный сыр, траву, фрукты, когда они дешевы, и пьет в небольшом количестве самое дешевое вино, не позволяя себе пользоваться никакими предметами роскоши». Определенное представление в обществе складывалось и о нахичеванских женщинах: «Семейные добродетели армянок известны: они мало выезжают, еще реже танцуют, они заняты мужем, цветами, детьми, а для развлечения смотрят на прохожих в просветы жалюзи, читают духовные книги, в девять вечера они уже ужинают и ложатся спать, сберегая свечи и здоровье. Они - хорошие хозяйки, бережливы...» (оба отрывка цит. по: Казаров 2009: 120-121). Однако сохранилось немало примеров того, что в ряде случаев, особенно став купеческими вдовами, нахичеванские женщины с успехом продолжали коммерческие дела своих мужей. Например, по данным статистического комитета на 1861-1862 гг. из 601 жителя Нахичевани купеческого сословия 280 человек составляли женщины-купчихи (Казаров 2009: 121).

В 1894 г. на центральной площади города был поставлен памятник Екатерине Великой работы известных в то время русских скульпторов Чижовых. На его пьедестале была высечена надпись: «Императрице Екатерине благодарные армяне», там же были указаны даты сооружения монумента, имелись барельеф архиепископа Иосифа Аргутинского и герб Нахичевани, а внутри установлен привезенный из Армении большой хачкар (Кринко 2012: 173). В 1917 г. этот памятник был снесен большевиками, а на его месте открыт памятник Карлу Марксу, не имевшему никакого отношения к Нахичевани. В 1959 г. здесь же был установлен новый памятник Карлу Марксу. При советской власти с Александровской колонны был снят позолоченный двуглавый орел. И только уже в наше время, в 1994 г., на средства ростовского предпринимателя Юрия Прокопьевича Рошкована колонна была отреставрирована и ее вновь увенчал двуглавый орел.

Нахичеванцы, особенно образованная интеллигенция, всегда проявляли любовь к театральному искусству. В 1860-х гг. уроженцы Нахичевани, братья Арцатбаняны со своими единомышленниками организовали первую театральную группу. В это время в их город (как и в другие российские города с армянским населением) приезжали на гастроли труппы армянских актеров из Стамбула, Тифлиса, Баку, в числе которых был и 
знаменитый актер того времени Петрос Иеронимович Адамян (1849-1891). Позднее в городе было создано Общество любителей драматического искусства, председателем которого в течение 38 лет был известный в городе присяжный-поверенный, гласный Городской думы, выпускник юридического факультета Московского университета Георгий Иванович Чубаров (1864-1930), являвшийся одновременно сценаристом, композитором и актером. Однако развитие театрального искусства затрудняло отсутствие здания собственного театра. Спектакли приходилось играть в помещениях гимназии или коммерческого клуба. Поэтому весной 1894 г. Общество любителей драматического искусства по своей инициативе обратилось с соответствующим ходатайством в Городскую думу, которое было удовлетворено, в том числе лично городским головой Минасом Ильичем Балабановым (1844-?). Проект театра был исполнен главным архитектором города, выпускником Санкт-Петербургской академии художеств Николаем Никитовичем Дурбахом (Дурбахян) (1858-1924), который создал в городе целый ряд сооружений, дошедших до наших дней. За свою многолетнюю безупречную службу он был награжден орденами Св. Святослава (1904) и Св. Анны 3-ей степени (1911), пять раз избирался гласным Городской думы Нахичевани.

Освящение выстроенного здания городского театра, удачно расположенного в центре Бульварной площади, состоялось 12 декабря 1899 г. Тогда же в театре состоялась премьера пьесы Л.Н. Толстого «Плоды просвещения» с участием актеров Николая Николаевича Синельникова, Марии Михайловны Блюменталь-Тамариной, Петровского и других. Театр был рассчитан на 600 зрителей и включал партер, амфитеатр, два яруса лож, балкон, галерею и фойе. Театральный занавес и декорации, а также висевшие на стенах фойе портреты В. Шекспира, Н. Гоголя, А. Островского, М. Глинки, П. Чайковского, Дж. Верди были расписаны известным живописцем и театральным художником из Новочеркасска Иваном Ивановичем Крыловым, стены - местным художником, выпускником Московского училища живописи, ваяния и зодчества Амаяком Абрамовичем Арцатбаняном. Ныне Нахичеванский театр называется Молодежным театром (Багдыков 2011: 15, 24; Казарова 2016: 231-234).

В начале XX в. в городе публиковалось несколько периодических изданий: в 1906 г. выходила газета «Нор кянк» («Новая жизнь»), в 1907 г. ее сменила газета «Мер дзайн» («Наш голос»). Обе газеты широко освещали происходившие в мире, стране, в Армении и в городе события. В 1910-1914 гг. под редакцией видного общественного деятеля, врача Геворка Реизяна печаталась газета «Луйс» («Свет»), в которой, в отличие от предшествующих газет, преобладали не политические материалы, а литературные и образовательные. В годы Первой мировой войны, в 1914-1916 гг, в городе под редакцией Саака Мясникяна выходил еженедельник «Гахут» («Колония»), который больше внимания уделял политическим вопросам. Кроме того, местные армяне активно сотрудничали с русскими газетами Ростова-на-Дону, а в ряде случаев были их основателями и редакторами. Так, газету «Приазовский край» в 1891-1911 гг. редактировал С. Арутюнян, В 1891 г. он выкупил право на издание газеты «Донское поле», после чего переименовал ее в «Приазовский край» и стал выпускать в обновленном виде. Эта газета очень скоро приобрела большую популярность на Юге России, на ее страницах печатался даже Антон Павлович Чехов. С. Арутюнян оставался ее редактором до конца своей жизни. Не менее популярную газету «Донская речь» редактировал уважаемый в городе М. Берберян, газету «Донская пчела» - известный книголюб А. Тер-Абраамян. Он же с конца XIX в. издавал 
на русском языке ежегодный «Донско-Азовский русско-армянский календарь», публиковавший разного рода справочные материалы и рассказывающий о жизни армянской колонии (Ананян. Хачатурян 1993: 106-107; Багдыков 2011: 41-42).

Известно, что новонахичеванские армяне оказывали значительную материальную и финансовую помощь российскому правительству во время русско-персидских и русско-турецких войн конца XVIII - начала XIX в., а также во время Отечественной войны 1812 г. с Наполеоном. Местное купечество своей активной предпринимательской деятельностью поддерживало связи не только с Арменией, но и с армянскими общинами разных стран Запада и Востока, содействуя тем самым развитию внешних торгово-экономических связей этих стран с Россией. С конца XIX в., с экономическим усилением соседнего Ростова, пользовавшегося правительственной поддержкой и потому быстро развивающегося, наиболее влиятельные армянские промышленники и купцы переселились в этот город, также в немалой степени способствуя его развитию (Казаров 2012: 140).

В то же время обычные горожане Нахичевани продолжали в своем быту сохранять многие традиции, присущие их предкам. Об этих традициях, различных жизненных эпизодах, передающих атмосферу тех дней в начале XX в. в жизни донских армян, рассказала в своей автобиографической книге «Человек и время» Мариэтта Сергеевна Шагинян, периодически посещавшая родную Нахичевань-на-Дону в 1910-1920 гг. и прожившая в ней более 5 лет с 1915 по 1920 гг. Так, она пишет: «Жизнь казалась там узкообособленной, монотонной, мелконациональной и, как масло с водой, совсем не сливавшейся с жизнью большого русского мира в Ростове по соседству, а тем более не похожей и на нашу московскую, русскую жизнь» (Шагинян 1982: 18: цит. по: Авдулов 2012: 315). Ею нарисованы выразительные портреты своих родственниц - сестер матери, которые в обязательном порядке соблюдали разного рода местные обычаи: «Тети - каждая - стоят у меня ярко в памяти, красивые, крепкие, хозяйственные, одаренные здравым смыслом и коренным упорством в поведении. Они верили в незыблемый распорядок жизни, в женские функции жен и матерей, в соблюдение обычаев, неизвестно кем и когда установленных: дни поминовения умерших, когда на кладбище надо нести пироги для раздачи нищим; визиты попа и дьякона в большие праздники, с заготовленными для них конвертами, первому толстому, второму потоньше; “соленье“ младенца при его крещении, изготовление "гаты“ и "губаты“ под рождество и множество всяких соблюдаемых правил и привычек» (Шагинян 1982: 17; цит. по: Авдулов 2012: 316).

В советское время город Нахичевань-на-Дону, образовав вместе с Ростовом-на-Дону крупный промышленный и культурный центр, практически слился с ним, а в декабре 1928 г. постановлением Административной комиссии при Президиуме ВЦИК СССР город Нахичевань был присоединен к Ростову, в результате они были объединены в единый город Ростов-на-Дону, в котором бывший город Нахичевань-на-Дону первое время существовал в виде Нахичеванского района, а затем в 1929 г. этот район был переименован в Пролетарский район. С тех пор историческое название основанного крымскими армянами города, сыгравшего значительную роль в развитии не только Ростова, но и всего Донского края, а также сохранявшего до этого времени свой национальный культурный облик, исчезло. Во время своей поездки в 1990 г. к донским армянам я в разговоре с губернатором Ростовской области Владимиром Федоровичем Чубом говорила ему, что пора уже переименовать Проле- 
тарский район и вернуть ему прежнее название Нахичеванский. Это было бы справедливым решением по отношению к донским армянам, испытавшим в свое время немало страданий от новой власти.

Еще накануне Гражданской войны жизнь на Дону, по словам М.С. Шагинян, протекала уравновешенно: «Из года в год в одноэтажных особнячках предместья Ростова, с лепными карнизами и приспущенными жалюзи на зеркальных окнах, жизнь текла привычным порядком. По вечерам, за полночь, сидели гости и играли в карты. Прислуга на кухне сквозь сон готовила, смотря по сезону, все тот же одинаковый ужин» (Шагинян 1971: 7-8, цит. по: Авдулов 2012: 316). Однако Гражданская война коренным образом перевернула жизнь людей. Везде - масса беженцев, дороговизна, всем руководит голая выгода. «Дом», формирующий человека, перестал быть «обителью», защитой, духовным гнездом. Он стал «кровлей», проходным местом. Война сдвинула человека с места. Стал теряться «домашний уют», отсюда - обесценивание дома как «семейного гнезда». М.С. Шагинян называет этот процесс, на глазах становящийся массовым, «могучим сдвигом в сознании обывателя». Вместо сущностного обладания приходит внешнее владение, накопление, стяжание. Старый быт убивает война, и наступает «междубытие» (Смирнов 2012: 388).

С установлением на Дону с января 1920 г. советской власти в последующие 1920-е - начале 1930-х гг. многим известным и уважаемым нахичеванцам пришлось пережить страшные ужасы и лишения со стороны большевиков. Лишь некоторые из них, как, например, М.И. Балабанов и М.Г. Мелконов-Езеков, сумели перевести часть своих капиталов и, захватив семейные ценности, бежать за рубеж. Самыми первыми шагами новой власти были предпринятые красноармейцами обыски в домах горожан в поисках золотых украшений, которые обычно хранились дома, а если их не находили, то изымали все, что им нравилось, при этом мужчин отправляли чистить отхожие места в казармах. Любому, не понравившемуся красноармейцам человеку могли грозить арест или даже расстрел. Тяжелым ударом для большинства горожан, добротные дома которых были построены собственными руками и в которых они и их предки жили долгие годы, стала проходившая в начале 1920-х годов так называемая «муниципализация», т.е. уплотнение, когда к одним армянским семьям подселяли прибывавших для работы на предприятиях «пролетариев» или служащих ВЧК-ОГПУ, а другие семьи, имевшие благоустроенные дома-особняки, переселяли в менее удобные помещения. Например, известный купец, гласный нахичеванской и ростовской Городской думы Иван Матвеевич Келле-Шагинов (1853-1932), много сил и времени отдавший благоустройству обоих городов, был вызван в ДонЧека, где ему под угрозой высылки в Архангельск было предложено покинуть Ростов и Нахичевань. В результате, лишив его, человека в 78-летнем возрасте, своего дома, вместе с больной женой выселили на окраину города, в холодное получердачное помещение без удобств, а у его жены конфисковали сундук, в котором она хранила свои платья и теплые вещи. В эти годы многие ограбленные нахичеванцы, потеряв свои дома и имущество, включая принадлежавшие им в прошлой жизни предприятия и заведения, были вынуждены устраиваться на «службу» за небольшой паек. Известная писательница (отец ее был нахичеванским армянином, а мать - русская, из семьи тверских помещиков Карауловых) Нина Николаевна Берберова (1901-1993), пишет в своих воспоминаниях, что она, живя в этот период в Нахичевани, служила в конторе Владикавказской железной дороги, получая в качестве пайка крупу и селедку, и очень боялась, что начальство, 
узнав, что она живет в собственном доме, может ее уволить (Берберова 1996: 23; цит. по: Казаров 2016: 238). Известный в Нахичевани купец Каспар Авдеевич Субашиев (1866-1947), который вел торговлю строительными материалами, лишившись при новой власти всего своего имущества, был вынужден поступить на службу агентом по снабжению, а затем, поскольку был образованным (а образованных людей не хватало), перешел на работу бухгалтером и счетоводом. Многие нахичеванцы, оказавшись в страшной нищете, страдая от голода, неустроенности быта и болезней, доживали свой век в непривычных для них условиях и тихо уходили из жизни. Последним скончался прямо на улице 1 марта 1939 г. от сердечного приступа видный общественный деятель, публицист, юрист, литератор и журналист Нахичевани, избиравшийся в течение 20 лет гласным Городской думы, выпускник Лазаревского института восточных языков Григорий Хачатурович Чалхушьян (1861 -1939), не выдержав ареста и расстрела всех четырех своих сыновей - в 1937 г. Серафима, в 1938 г. - Леона и Степана, в 1939 г. - Рубена (Казаров 2016: 235-239).

С приходом новой власти и начавшимися массовыми репрессиями страдали не только люди, особенно интеллигенция и купечество, но были уничтожены многие историко-архитектурные памятники, в частности, снесен монумент Екатерине II, было разрушено шесть из семи армянских храмов (наряду с православными церквями, мечетью и синагогой); закрытый еще в 1920 г. монастырь Сурб Хач постепенно ветшал, и в середине 1960-х годов, когда от него оставалась только одна церковь, его хотели снести, а на его месте построить школу; спасло здание только создание в этой церкви в 1972 г. Музея русско-армянской дружбы как филиала Ростовского областного музея краеведения (Кринко 2012: 173). В наши дни Сурб Хач признан архитектурным памятником федерального значения и передан в пользование Армянской апостольской церкви. В 2008 г. во время своего визита в Ростов католикос всех армян Гарегин Второй посетил храм Сурб Хач и принял участие в торжественном богослужении и его освящении. Теперь в нем проходят религиозные богослужения. Музей русско-армянской дружбы был переведен в здание бывшего особняка армянского купца Марка Яковлевича Искидарова, находящееся на площади Свободы в историческом центре Нахичевани. В декабре 2017 г. ростовская общественность торжественно отметила 45-летие этого музея, ставшего значимым культурно-просветительским центром, в котором проходят презентации книг ростовских авторов (Багдыков 2018).

Постепенно в городе стало сокращаться число армянских учебных заведений (еще до Великой Отечественной войны их было 15, в том числе Армянский педагогический техникум); перестал функционировать Армянский театр, и город вместе с историческим названием начал утрачивать свою роль важного очага армянской культуры на Юге России.

Значительный вклад в сохранение этнокультурной самобытности донских армян, в содействие сохранению и упрочению гражданского мира и согласия в обществе, укрепление деловых и культурных связей с Арменией, в поддержку молодых талантов стала вносить созданная в 1988 г. одна из крупных армянских общин России «Ново-Нахичеванская-на-Дону армянская община». Первым ее председателем был избран Крикор Дзеронович Хурдаян, по инициативе которого она была создана. В наши дни главой общины стал известный предприниматель Арутюн Арменакович Сурмалян. В 2005 г. он стал председателем Совета армянского общества «Нор-Нахи- 
чеван», в 2012 г. - президентом этой организации. При его активном участии силами общины в Ереване был открыт мемориальный комплекс казакам-героям, погибшим на территории Армении в ходе русско-турецких и русско-персидских войн конца $\mathrm{XIX}$ - начала XX в., подписаны договоры о побратимских отношениях между городами Ереваном и Ростовом-на-Дону.

Из среды донских армян вышло немало выдающихся личностей: просветитель, писатель и публицист Микаел Лазаревич Налбандян (1829-1866), один из основоположников армянской гражданской поэзии Рафаел Габриэлович Патканян (1830-1892), востоковед, член-корреспондент Санкт-Петербургской академии наук, профессор Санкт-Петербургского университета Керопэ Петрович Патканян (18331889), католикос всех армян Геворг VI Чорекчян (1868-1954), известный историк и искусствовед Алексей Карпович Дживелегов (1875-1952), крупнейший живописец-пейзажист Мартирос Сергеевич Сарьян (1880-1972) и талантливый художник Григор Иванович Шилтян (1896-1985), писательницы Мариэтта Сергеевна Шагинян (1888-1982) и Нина Николаевна Берберова (1901-1993), выдающийся скрипач, лауреат Государственных премий СССР и Армянской ССР Авет Карпович Габриэлян (1899-1983), известные архитекторы Мирон Оганесович Мержанов (1895-1975) и Марк Владимирович Григорян (1900-1978), историк мировой архитектуры Оганес Хачатурович Халпахчьян (1907-1996), крупные ученые-физиологи Михаил Христофорович Чайлахян (1902-1991) и Рубен Александрович Будагов (1910-2001), летчик-истребитель Лазар Сергеевич Чапчахов (1911-1942), легендарный разведчик Геворк Андреевич Вартанян (1924-2012), профессора - композитор и музыковед Гаяне Моисеевна Чеботарян (1918-1998) и дирижер Аристакес Григорьевич Каспаров (1916-1989), щестикратный чемпион России, двукратный чемпион Европы и мира, чемпион Олимпийских игр Вартерес Вартересович Самургашев (1979) и многие другие известные донские армяне.

В заключение отмечу, что несмотря на то, что данная группа армян более девяти столетий проживала в диаспоре (начиная с XI в. в Крыму) и из них уже 240 лет на российской земле, вдали от этнической родины и в окружении главным образом русского населения, с которым она имеет постоянные контакты в разных областях жизнедеятельности, в том числе и заключая межнациональные браки, в целом ей удалось до наших дней во многом сохранить свой этнокультурный облик (национальную идентичность, при свободном владении русским языком язык своего народа в виде диалекта западноармянского варианта литературного языка, приверженность к Армянской апостольской церкви, немало традиций в праздничной и ритуальной пище, в семейно-бытовой сфере, особенно в обрядности) и не раствориться в среде преобладающего на данной территории этноса. Устойчивости этнокультурного облика не помешало также то, что за долгие столетия проживания в диаспоре эта группа, естественно, многократно испытывала на себе и определенное ассимиляционное давление, в частности, в связи с целенаправленной политикой государства в советский период. В наше время, на фоне возрождающегося интереса к своей истории, нахичеванцы все чаще стали высказывать пожелания о возвращении основанному их предками городу его исторического названия, что стало бы актом большого нравственного значения, тем более, что в народном быту это название нередко по-прежнему употребляется. 


\section{Научная литература}

Авдулов Н.С. Нахичевань в жизни и творчестве Мариэтты Шагинян // Армяне Юга России: история, культура, общее будущее. Материалы всероссийской научной конференции «Армяне Юга России: история, культура. общее будущее» (30 мая - 2 июня 2012 г. г. Ростов-на-Дону) / отв. ред. Г.Г. Матишов. Ростов-на-Дону: ЮНЦ РАН (Южный научный центр Российской академии наук), 2012. С. 314-318.

Ананян Ж.А., Хачатурян В.А. Армянские общины России. Ереван: изд-во М. Варандян, 1993. $120 \mathrm{c}$.

Багдыков Г. Прогулки по Нахичевани. Ростов-на-Дону: Книга, 2011. 78 с.

Багдыков Г. 45 лет Музею русско-армянской дружбы // Газета «Ноев ковчег». Москва: 2018, № 3 (302). Март.

Багдыков М.Г. Нахичеванские портреты. Ростов-на-Дону: Ростовское книжное изд-во, 1991. $96 \mathrm{c}$.

Бархударян В.Б. История армянской колонии Новая Нахичевань. 1779-1917. Ереван: Айастан, 1996. $528 \mathrm{c.}$

Берберова Н.Н. Курсив мой. Москва: Согласие, 1996. 736 с.

Вартанян В.Г., Казаров С.С. История Армянской апостольской церкви на Дону (XVIIIХХ вв.). Таганрог: ТИУИЭ (Таганрогский институт управления и экономики), 2008. $120 \mathrm{c.}$

Геворгян Г.Г. Образ Иосифа Аргутинского в работе Лео // Армяне Юга России: история, культура, общее будущее. Материалы всероссийской научной конференции «Армяне Юга России: история, культура, общее будущее» (30 мая - 2 июня 2012 г., г. Ростов-на-Дону) / отв. ред. Г.Г. Матишов. Ростов-на-Дону: ЮНЦ РАН, 2012. С. 340-345.

Поповян Г.А. (сост.) 210 лет в единой семье (1779-1989). Чалтырь: Фабрика цветной печати г. Ростов-на-Дону, 1989. 21 с.

Казаров С.С. Армянское купечество Нахичевана-на-Дону // Третьи Лазаревские чтения по истории армян России. Москва, 3-6 июня 2006 г. / Сост. и ред. Э.Е. Долбакян. Москва: МАКС Пресс, 2009. С. 118-122.

Казаров С.С. Нахичеванское купечество (конец XVIII - начало XX века). Ростов-на-Дону: Ковчег. 2012. $144 \mathrm{c.}$

Казаров С.С. Об одном забытом источнике о переселении армян из Крыма на Дон // Армяне Юга России: история, культура. общее будущее. Материалы II международной научной конференции «Армяне Юга России: история, культура, общее будущее» (26 - 28 мая 2015 г., г. Ростов-на-Дону) / отв. ред. Г.Г. Матишов. Ростов-на-Дону: ЮНЦ РАН, 2015. С. 28-32.

Казаров С.С. Судьбы нахичеванцев в 1920 - начале 1930-х годов в исторической памяти // Армяне Поволжья и Юга России: история и современность. Материалы II всероссийской научной конференции «Армяне Поволжья и Юга России: история и современность» (Саратов, 15-16 апреля 2016 г.) / отв. ред. В.А. Чолахян. Саратов: Изд. центр Наука, 2016. С. 235-239.

Казарова Н.A. Нахичеванский театр и его роль в культурной жизни донских армян // Армяне Поволжья и Юга России: история и современность. Материалы II всероссийской научной конференции «Армяне Поволжья и Юга России: история и современность» (Саратов. 1516 апреля 2016 г.) / отв. ред. В.А. Чолахян. Саратов: Изд. центр Наука, 2016. С. 232-234.

Кринко Е.Ф. История армян Юга России: мемориальная версия // Армяне Юга России: история, культура, общее будущее. Материалы всероссийской научной конференции «Армяне Юга России: история, культура, общее будущее» (30 мая - 2 июня 2012 г. г. Ростов-на-Дону) / отв. ред. Г.Г. Матишов. Ростов-на-Дону: ЮНЦ РАН, 2012. С 171-177.

Патканян Р. История основания Нахичевани-на-Дону // Патканян Р. Собрание сочинений в шести томах. Т. 5. Ереван: Академия наук Армянской ССР, 1968. С. 253-271 (на арм. яз.). Сармакешян Г. У самого Тихого Дона // Газета «Коммунист». Ереван, 1990. 23.05.

Смирнов В.В. Публицистика М. Шагинян в «Приазовском крае» (1918-1919 гг.): актуаль- 
ность культурно-исторической тематики // Армяне Юга России: история, культура, общее будущее. Материалы всероссийской научной конференции «Армяне Юга России: история, культура, общее будущее» (30 мая - 2 июня 2012 г., г. Ростов-на-Дону) / отв. ред. Г.Г. Матишов. Ростов-на-Дону: ЮНЦ РАН, 2012. С. 383-389.

Черняховский С., Черняховская Ю. Вершина Крыма. Крым в русской истории и крымская самоидентификация России. От античности до наших дней. Москва: Книжный мир, 2015. $406 \mathrm{c}$.

Шагинян М.С. Перемена // Собрание сочинений в девяти томах Т. 2. Москва: Художественная литература, 1971.

Шагинян М. Человек и время. История человеческого становления. Москва: Художественная литература, 1982.

\section{References}

Ananian, Zh.A., and V.A. Khachaturian. 1993. Armianskie obshchiny Rossii. [Armenian communities of Russia], 120. Erevan: izd-vo M. Varandian.

Avdulov, N.S. 2012. Nakhichevan' v zhizni i tvorchestve Marietty Shaginian [Nakhchivan in the life and work of Marietta Shaginyan]. In Armiane Iuga Rossii: istoriia, kul'tura, obshchee budushchee. Materialy vserossiiskoi nauchnoi konferentsii "Armiane Iuga Rossii: istoriia, kul'tura, obshchee budushchee» (30 maia - 2 iiunia 2012. Rostov-na-Donu) [Armenians of the South of Russia: history, culture, common future. Materials of the All-Russian Scientific Conference "Armenians of the South of Russia: History, Culture. common future "(May 30 June 2, 2012 Rostov-on-Don)], edited by. G.G. Matishov, 314-318.

Bagdykov, G. 2011. Progulki po Nakhichevani. [The promenados through Nakhichevani], 78. Rostov-Don: Kniga.

Bagdykov, G. 2018. 45 let Muzeiu russko-armianskoi druzhby [45 years of Russian-Armenian friendship museum]. Gazeta "Noev kovcheg", 3 (302). Mart.

Bagdykov, M.G. 1991. Nakhichevanskie portrety. [The portraits of Nakhichevan]. Rostov-Don: Rostovskoe knizhnoe izd-vo.

Barkhudarian, V.B. 1996. Istoriia armianskoi kolonii Novaia Nakhichevan'. 1779-1917. [History of the Armenian colony of New Nakhichevan. 1779-1917]. Erevan: Aiastan.

Berberova, N.N. 1996. Kursiv moi. [The italics are mine]. Moscow: Soglasie.

Cherniakhovskii, S., and Iu. Cherniakhovskaia. 2015. Vershina Kryma. Krym v russkoi istorii $i$ krymskaia samoidentifikatsiia Rossii. Ot antichnosti do nashikh dnei. [The top of Crimea in the Russian history and creamean selfidentify of Russia. From antiquity to our days]. Moscow: Knizhnyi mir.

Gevorgian, G.G. 2012. Obraz Iosifa Argutinskogo v rabote Leo [The image of Joseph Argutinsky in the work of Leo]. In Armiane Iuga Rossii: istoriia, kul'tura. obshchee budushchee. Materialy vserossiiskoi nauchnoi konferentsii "Armiane Iuga Rossii: istoriia, kultura, obshchee budushchee' (30 maia - 2 i.iunia 2012 g., g. Rostov-na-Donu) [The image of Iosef Argoutinsky in the work of Leo. In: Armenians of the South of Russia: history, culture, common future, ed. by G.G. Matishov. Materials of All-Russian scientific conference], edited by G.G. Matishov, 340-345. Rostov-Don: IuNTs RAN.

Kazarov, S.S. 2009. Armianskoe kupechestvo Nakhichevana-na-Donu [About one forgotten source about the resettlement of Armenians from Crimea to the Don]. In Tret'i Lazarevskie chteniia po istorii armian Rossii. Moskva, 3-6 iiunia 2006 g. [The Armenian merchantry of NakhichevanDon. In: The Third Lazarev Reading on the history of Armenians of Russia, ed. and compos. by E.E. Dolbakian], edited by E.E. Dolbakian, 118-122. Moscow: MAKS Press.

Kazarov, S.S. 2012. Nakhichevanskoe kupechestvo (konets XVIII - nachalo XX veka). [The merchantry of Nakhichevan (from end XVIII to beginning XX century]. Rostov-Don: Kovcheg. Kazarov, S.S. 2015. Ob odnom zabytom istochnike o pereselenii armian iz Kryma na Don [About 
one forgotten source about the resettlement of Armenians from Crimea to the Don]. In Armiane Iuga Rossii: istoriia, kul'tura. obshchee budushchee. Materialy II mezhdunarodnoi nauchnoi konferentsii "Armiane Iuga Rossii: istoriia, kul'tura. obshchee budushchee" (26-28 maia 2015 g., g. Rostov-na-Donu). [Armenians of the South of Russia: history, culture, common future, ed. by G.G. Matishov. Materials of II International scientific conference], edited by G.G. Matishov, 28-32. Rostov-Don: IuNTs RAN.

Kazarov, S.S. 2016. Sud'by nakhichevantsev v 1920 - nachale 1930-kh godov v istoricheskoi pamiati [The destinies of people of Nakhichevan in 1920 - early 1930 years in the historical memory]. In Armiane Povolzh'ia i Iuga Rossii: istoriia i sovremennost'. Materialy II vserossiiskoi nauchnoi konferentsii "Armiane Povolzh'ia i Iuga Rossii: istoriia i sovremennost" (Saratov, 15-16 aprelia 2016 g.) [Armenians of the Volga Area and of the South of Russia: the history and contemporary status. Materials of the Second All-Russian scientific conference], edited by V.A. Cholakhian, 235-239. Saratov: Nauka.

Kazarova, N.A. 2016. Nakhichevanskii teatr i ego rol' v kul'turnoi zhizni donskikh armian [The theatre of Nakhichevan and its role in cultural life of Armenians of Don]. In Armiane Povolzh'ia $i$ Iuga Rossii: istoriia i sovremennost'. Materialy II vserossiiskoi nauchnoi konferentsii “Armiane Povolzh'ia i Iuga Rossii: istoriia i sovremennost”" (Saratov. 15-16 aprelia 2016 g.) [Armenians of the Volga Area and of the South of Russia: the history and contemporary status. Materials of the Second All-Russian scientific conference], edited by V.A. Cholakhian, 232-234. Saratov: Nauka.

Krinko, E.F. 2012. Istoriia armian iuga Rossii: memorial'naia versiia [The history of Armenians of the South of Russia: the memorial version]. In Armiane Iuga Rossii: istoriia, kul'tura, obshchee budushchee. Materialy vserossiiskoi nauchnoi konferentsii "Armiane Iuga Rossii: istoriia, kul'tura, obshchee budushchee' (30 maia - 2 iiunia 2012 g. g. Rostov-na-Donu) [Armenians of the South of Russia: history, culture, common future, ed. by G.G. Matishov. Materials of AllRussian scientific conference], edited by G.G. Matishov, 171-177. Rostov-Don: IuNTs RAN.

Patkanian, R. 1968. Istoriia osnovaniia Nakhichevani-na-Donu [The history of foundation of Nakhichevan-Don]. In Sobranie sochinenii v shesti tomakh [Complete works 6 vols.], vol. 5. Erevan: Academy of Sciences of the Armenian SSR, 253-271 (In Armenian).

Popovian, G.A. 1989. 210 let v edinoi sem'e (1779-1989) [210 years in the united family]. Chaltyr': Fabrika tsvetnoy pechati Rostov-Don.

Sarmakeshian, G. 1990. U samogo Tikhogo Dona [At the Quietest Don]. Gazeta "Kommunist". 23 may.

Smirnov, V.V. 2012. Publitsistika M. Shaginian v “Priazovskom krae' (1918-1919 gg.): aktual'nost' kul'turno-istoricheskoi tematiki [Journalism M. Shaginyan in the Priazovsk Territory (19181919): relevance of cultural and historical subjects]. In Armiane Iuga Rossii: istoriia, kul'tura, obshchee budushchee. Materialy vserossiiskoi nauchnoi konferentsii "Armiane Iuga Rossii: istoriia, kul'tura, obshchee budushchee' (30 maia - 2 iiunia 2012 g., g. Rostov-na-Donu) [Armenians of the South of Russia: history, culture, common future. Materials of the AllRussian Scientific Conference "Armenians of the South of Russia: History, Culture, Common Future" (May 30 - June 2, 2012, Rostov-on-Don)], edited by G.G. Matishov, 383-389. RostovDon: IuNTs RAN.

Shaginian, M.S. 1971. Peremena [The change]. In Sobranie sochinenii v deviati tomakh. Vol. 2. [Complete works 9 vols. Vol.2]. Moscow: Khudozhestvennaia literature.

Shaginian, M. 1982. Chelovek i vremia. Istoriia chelovecheskogo stanovleniia. [The man and time. History of human formation]. Moscow: Khudozhestvennaia literatura.

Vartanian, V.G., and S.S. Kazarov. 2008. Istoriia Armianskoi apostol'skoi tserkvi na Donu (XVIII$X X v$ v.). [History of Armenian apostolic church on Don (XVIII - XX centuries]. Taganrog: TIUIE (Taganrogskii institut upravleniia i ekonomiki). 
Ter-Sarkisyants, Alla E.

\section{Years on Russian Soil (The history of the town of New Nakhichevan founded by Armenian settlers)}

The article is devoted to the history of a settlement founded in 1779 by Armenian settlers who were relocated by an order of Catherine the Great from Crimea to Russia. They were granted various privileges and the new town was successfully developing thanks to intensive trade, crafts and industries, charity activities that favoured extensive construction of schools, churches, a theatre, a museum and other cultural institutions. As a result, it became one of important economic and cultural centers in the South of Russia. However, in December 1928 it was merged with the neighbouring and rapidly developing city of Rostov-on-Don. First, it retained the original name Nakhichevanski as a district within the city of Rostov, but in 1929 it was given a rather meaningless name Proletarski district. Thus, the historical name of the town where the traditional way of life prevailed and many outstanding Armenians had been born gradually disappeared and later the population suffered considerably in Stalinist purges of 1920-1930-s. Today the Armenians of the Don Basin show increasing interest to their history and begin to demand a restoration of the original name of the town. This would be an act of a great moral value.

Key words: Armenian settlers, new town, intensive trade, crafts, industry, cultural objects 